\title{
Article
}

\section{Corporate Governance: The Impact of Director and Board Structure, Ownership Structure and Corporate Control on the Performance of Listed Companies on the Ghana Stock Exchange}

Darko, Josephine, Aribi, Zakaria and Uzonwanne, Godfrey

Available at http://clok.uclan.ac.uk/14336/

Darko, Josephine, Aribi, Zakaria ORCID: 0000-0001-7772-2341 and Uzonwanne, Godfrey (2015) Corporate Governance: The Impact of Director and Board Structure, Ownership Structure and Corporate Control on the Performance of Listed Companies on the Ghana Stock Exchange. Corporate Governance: The international journal of business in society, 16 (2). pp. 259277.

It is advisable to refer to the publisher's version if you intend to cite from the work. http://dx.doi.org/10.1108/CG-11-2014-0133

For more information about UCLan's research in this area go to http://www.uclan.ac.uk/researchgroups/ and search for <name of research Group>.

For information about Research generally at UCLan please go to http://www.uclan.ac.uk/research/

All outputs in CLoK are protected by Intellectual Property Rights law, including Copyright law. Copyright, IPR and Moral Rights for the works on this site are retained by the individual authors and/or other copyright owners. Terms and conditions for use of this material are defined in the policies page. 


\title{
Corporate Governance: The Impact of Director and Board Structure, Ownership Structure and Corporate Control on the Performance of Listed Companies on the Ghana Stock Exchange
}

\begin{abstract}
Purpose - This paper seeks to examine the relationship between corporate governance and firm performance of listed Ghanaian companies.

Design/Methodology/approach - The study adopts a longitudinal and cross-sectional data set of 20 sampled companies over a period of 5 years. The data was analysed using a panel regression and ANOVA analysis to establish the relationship between corporate governance and firm performance. Corporate governance is defined in terms of three indices -board structure, ownership structure and corporate control while firm performance is measured by return on assets, return on equity, net profit margin and Tobin's Q.

Findings - The findings of the study revealed that, top twenty ownership structures and female representation on board have significant positive relationship with firm performance, while board independence and frequency of audit committee meeting have negative significant relationship with firm performance.
\end{abstract}

Research limitations/implications - The scope of this study can be expanded to include non-listed firms. In addition, other corporate governance mechanisms could be considered to broaden the scope of the study.

Originality/value -The originality of the paper is attributable to the use of two (2) data analysis techniques (panel regression analysis and ANOVA) which provides a comprehensive analysis on the relationship between corporate governance and firm performance. This, to the best knowledge of the authors, is the first of its kind to be done in Ghana.

Keywords - Corporate governance, board of directors, ownership structure, corporate control, firm performance, Ghana.

Paper type - Research paper 


\section{Introduction}

It is evidence that Good corporate governance provides the ability to improve competitive advantage, efficiency and effectiveness of companies (Maher and Anderson, 1999). As a result, stakeholders have begun to realise the importance of good corporate governance practices in protecting their interests. The empirical work on corporate governance and its impact on firm performance has growing remarkably in recent years especially in developing countries. There are little research has looked at corporate governance in developing countries such as Ghana. Previous studies also provide mixed findings on the directions of causality between corporate governance and firm performance. In this context, this paper attempt to examine the relationship between corporate governance and firm performance in Ghana. The Ghanaian business environment is characterised by a good level of growth and further growth is expected because of the recent discovery of oil in the country. This has resulted in the increased awareness of the effects of corporate governance on the performance of firms in Ghana. The study adopts a longitudinal and cross-sectional data set of 20 sampled companies over a period of 5 years. Our findings are useful for the policy community who are concerned with the impact of governance structure on corporate disclosure.

The reminder of the paper is structured as follows. Section 2 provides an overview of prior literature, which explore the relationship between corporate governance and firm performance, and development of hypothesis. Section 3 presents our research design. The main results are discussed in section 4 , and we provide a summary of our results and conclusion in section 5 .

\section{Background of Ghana}

Ghana, a developing country located in the West African Sub region is categorised amongst countries often faced with poor economic performance, weak legal and regulatory frameworks, illiquid stock markets and very frequent market intervention by government agencies (Tsamenyi et al, 2007). These structural characteristics have led to the demand for good corporate governance in Ghana and similar countries (Ahunwan 2002). Ghana does not have a specific corporate governance code such as the United Kingdom (principles based) and the United States (rules based). This means that companies tend to operate on a different 
set of corporate governance guidelines (Koranteng, 2004). Nonetheless, the Ghana Stock Exchange and the Security Exchange Commission serve as the primary regulators of all listed companies ensuring that all listing requirements and regulations are adhered to while also ensuring that these companies adhere to good corporate governance measures. In this regard, emphasis must be placed on the effects good corporate governance has on firm performance to help improve the effectiveness and efficiency of listed firms.

\section{Corporate governance and Firm Performance}

The Organisation of Economic Cooperation and Development (OECD, 1999), defines corporate governance as the mechanism or the system by which businesses and organisations are directed and controlled. The OECD indicates that the adoption of good corporate practices has the ability to increase and restore shareholder confidence as well as economic efficiency and growth (OECD, 2004). According to Sheikh and Rees (1995), the concept of corporate governance is grounded mainly in the accountability of directors to shareholders in lieu of their responsibilities in ensuring wealth maximisation. Corporate governance is a set of mechanisms that aims to direct managerial decisions and helps improve the firms' performance (Jarboui, Guetat, Boujelbene, 2015), while Vintila and Gherghina (2012) emphasised the fact that corporate governance mechanisms have the ability to mitigate the agency problem by aligning the interests of managers and directors with those of the shareholders. A number of previous studies investigated the role of governance mechanisms in resolving conflicts of interest between shareholder and managers and in improving performance (see e.g. Cubbin \& Leech, 1983; Aydin, Sayim, \&Yalama, 2007). However, the findings of these empirical studies are contradictory and inconclusive. The indecisive nature of the literature as it relates to whether there is any relationship existing between the firm performance and corporate governance is been operated calls for this paper.

\section{Board of Directors}

The key role of the board of directors is to monitor management decisions. Cadbury report (1992) identifies the board of directors' responsibilities as setting the company's strategic aims, providing the leadership to put them into effect, supervising the management of the business and reporting to shareholders on their stewardship. Boards of directors are typically 
measured by two characteristics: board composition and board size with either characteristic, there is a trade-off between more information and more effective decision-making. According to agency theory, non-executive directors can play key role in monitoring management performance. Having a higher proportion of outside non-executive directors on the board would result in better monitoring of the activities by the board and limit managerial opportunism (Fama, 1980; Fama and Jensen, 1983). Thus, it is expected that having more outside directors on the board will enhance the firm performance. Previous studies find relationship between board composition and profitability of firms in the sense that as the number of independent directors increased the higher the level of firm performance (Abor and Biekpe,2007) . These findings emphasise the need for non-executive directors. Chen et al., (2006) and Lo et al., (2010) added that greater board independence results in the reduction of fraudulent activities and the misappropriation of scare resources. As implied by resource dependence theory, non-executive directors with their expertise, knowledge, prestige and contacts, provide firms with links to external environment ( Wang and Hussainey, 2013). We expect a positive association between the number of non-executive directors and form performance. This lead to our first hypothesis:

H1: A positive association exists between number of non-executive directors and firm performance.

It has been argued that larger boards result in high performance due to the increased opportunities arising from diversity - gender, level of experiences, skills, expertise and nationality, networking and planning previous studies have investigated the association between board size and firm performance (Kiel and Nicholson, 2003; Dalton and Dalton, 2005; Adam and Mehran, 2005). Earlier works on the relationship between board size and firm performance have often been attributed to Lipton and Lorsch (1992), Jensen (1993) who supports smaller boards as being more efficient than larger ones. Yermack (1996) examines large US firms from 1984 to 1991 and finds a strong negative effect of board size on Tobin's q. Eisenberg et al., (1997) present evidence that a negative correlation between board size and profitability. In the same vein, Jensen (2012), found that keeping small boards can help to improve their performance and concludes that when board gets beyond seven or eight members they are less likely to function effectively. We expect that large board of directors leads to low performance. This lead to our second hypothesis: 
H2: A negative association exists between size of directors and firm performance.

Van der Walt and Ingley (2003) define diversity in the context of corporate governance as the structure of the board and the combination of the different qualities, characteristics and expertise of the individual members in relation to decision-making and other processes within the board. The level of Board diversity affects their decisions and might also contribute to the discussion, exchange of ideas and performance of the group (Kang, Cheng and Grey, 2007). Gender diversity on board is a highly debated topic, which has received a tremendous amount of attention of policy makers, researchers and shareholders (Chapple and Humphrey 2014). Davies Report (2011) has offered a business case for increasing the number of women on corporate boards and its potential impact on performance. In fact, substantial research is epidemic in the women-on-boards and suggests that companies with a strong female representation at board and top management level perform better than those without. (e.g. Adams et al. 2009; Campbell and Mínguez-Vera 2008; Farrell and Hersch 2005; Carter et al. 2003; Erhardt et al. 2003). Hence, it is expected that more female directors on board will increase improve the firm performance. This lead to our third hypothesis:

H3: A positive association exist between the presence of female on board of directors and firm performance

\section{Ownership Structure}

The ownership structure has the ability to shape the corporate governance system in any given country (Zhuang, 1999). The ownership structure is presented in terms of block holder ownership and state ownership. Substantial shareholders are expected to have the power and incentive to monitor management. The level of concentration of the ownership structure has implications such as large shareholders dominating decision making to the detriment of small shareholders (Kuznetsov and Muravyev, 2001). In other words, companies with concentrated ownership have less agency problems (Alnajjar and Abed , 2014; Zhuang,1999). However, the influence of block holder ownership on firm performance has received mixed results. Previous studies examined the relationship between and performance and find positive relation exists between ownership concentration and profitability (Cubin \& Leech,1983; Xu and Wang, 1999; Hiraki et al., 2003; Heugens et al., 2009 ). They show the important role of large shareholders and how the market value is positively related to increasing values of shares held by larger shareholders. Nevertheless, other stream of studies contradict this view 
and have emphasized another source of agency problem created by rising ownership concentration that gives more power to a circumscribed number of shareholders, that in turn might expropriate value from minority shareholders (La Porta, Lopez-de-Silanes, \& Shleifer, 1999). Similarly, Shah et al. (2012) demonstrating that an increase in the concentration levels of ownership structure leads to a reduction in good practises by firms. Nevertheless, we expect that block holder ownership led to high firm performance. This lead to our fourth hypothesis:

H4: A positive association between block holder ownership and firm performance.

The association between State ownership and firm performance has motivated many empirical studies. Porta et al. (1999) argue that the incentive for government to own shares in firm might be related to achieving political objectives rather than economic objectives. On the other hand Eng and Mark (2003) clime that government ownership reduce the problems of asymmetric information that result from the imperfect information about the value of the company. However, the empirical evidence for the relationship between firm performance and state ownership has been mixed results. Some studies report a positive effect of government ownership on firm performance (e.g. Bos 1991; Jiang et al., 2008; Liao and Young, 2012), while other studies present a negative effect (Chen et al., 2005, Wei, 2007; Mahmood and Abbas, 2011). Based on the above discussion we expect that State ownership lead to lower performance. This lead to our fifth hypothesis:

H5: A negative association between State ownership and firm performance.

\section{Audit Committee}

The role of the Audit committee in most companies is to monitor the integrity of their financial statement as well as the announcements of financial performance. Okeahalam, (2004) added that it is the duty of the audit committee to bring to the notice of the board of directors all issues that require special attention. The size of the audit committee is considered to be relevant to the effective discharge of its duties (Cadbury Committee, 1992). A number of corporate governance reports mandates that audit committees consist of a minimum of four directors (e.g. BRC, 1999; New York Stock Exchange, 2002; CMA, 2006). It is argued that a larger committee has greater organizational status and authority and a wider knowledge base (Kalbers and Fogarty, 1993; Braiotta, 2000). There are number of studies 
reported positive relationship between board size and firm performance (see. e.g. Dalton et al., 1999; Saleh et al., 2007; Mir \& Souad, 2008). On the other hand, Vafeas (1999) suggest that larger audit committee can lead to inefficient governance, because of yielding frequent meetings, which leads to increased expenses, and therefore negatively affect firm performance. Thus, large audit committee board is more likely to result in low firm performance. This lead to our sixth hypothesis:

H6: A negative association between audit committee size and firm performance.

The frequency of Audit committee meeting is used in prior research to measure the effectiveness of audit meeting. It has been argued that inactive audit committees are unlikely to monitor management effectively (Menon and Williams, 1994). Saleh et al., (2007) argued that audit committee with a small number of meetings is less likely to possess good role of monitoring. Abbott et al. (2004) find that audit committees of firms restating their financial statements are not likely to meet at least four times a year. A positive relationship was established between the frequency of audit committee meetings and firm performance (see e.g. Raghunandan and Rama,2007; Sharma et al., 2009). On the other hand, Rebeiz and Salameh (2006) found there is no relationship between audit committee meeting frequency and firm performance. Their finding was supported in research conducted by Sharma et al., (2009). Based on the above discussion we expect a positive association between the frequency of audit committee meeting and firm performance. This lead to our seventh hypothesis:

H7: A positive relationship between frequency of audit committee meeting and firm performance

\section{Methodology and Data}

Data Description

This study focuses on 20 of the 34 listed companies on the Ghana Stock Exchange across a 5 year period (2008 to 2012). A purposive sample of at least one company from every industry on the Stock exchange was selected to enable a true representation of the entire population. The data set for the research was primarily secondary data consisting of longitudinal and cross-sectional data. The sources of data include annual reports and financial statements of the listed companies. Variables such as return on equity (ROE), return on assets (ROA), net 
profits margin (NPM) and Tobin's Q (TBQ) were adopted. Director information and Board Structure, Board gender, Ownership and Corporate Control information was acquired from the websites and annual reports of the various companies with additional information also sought directly from the Ghana Stock Exchange. A pool panel regression and an ANOVA analysis was used to establish the presence or otherwise of a significant relationship between the dependent and independent variables while controlling for age ,size and leverage ratio of the firm. In this study, corporate governance structure was considered as the independent variable while corporate performance was taken to be the dependent variable. The study adopts four performance indicators to provide a deeper insight and basis of comparison. Tables 1.0 and 2.0 present the operational definitions adopted in the research.

Table 1.0 Operational Definitions

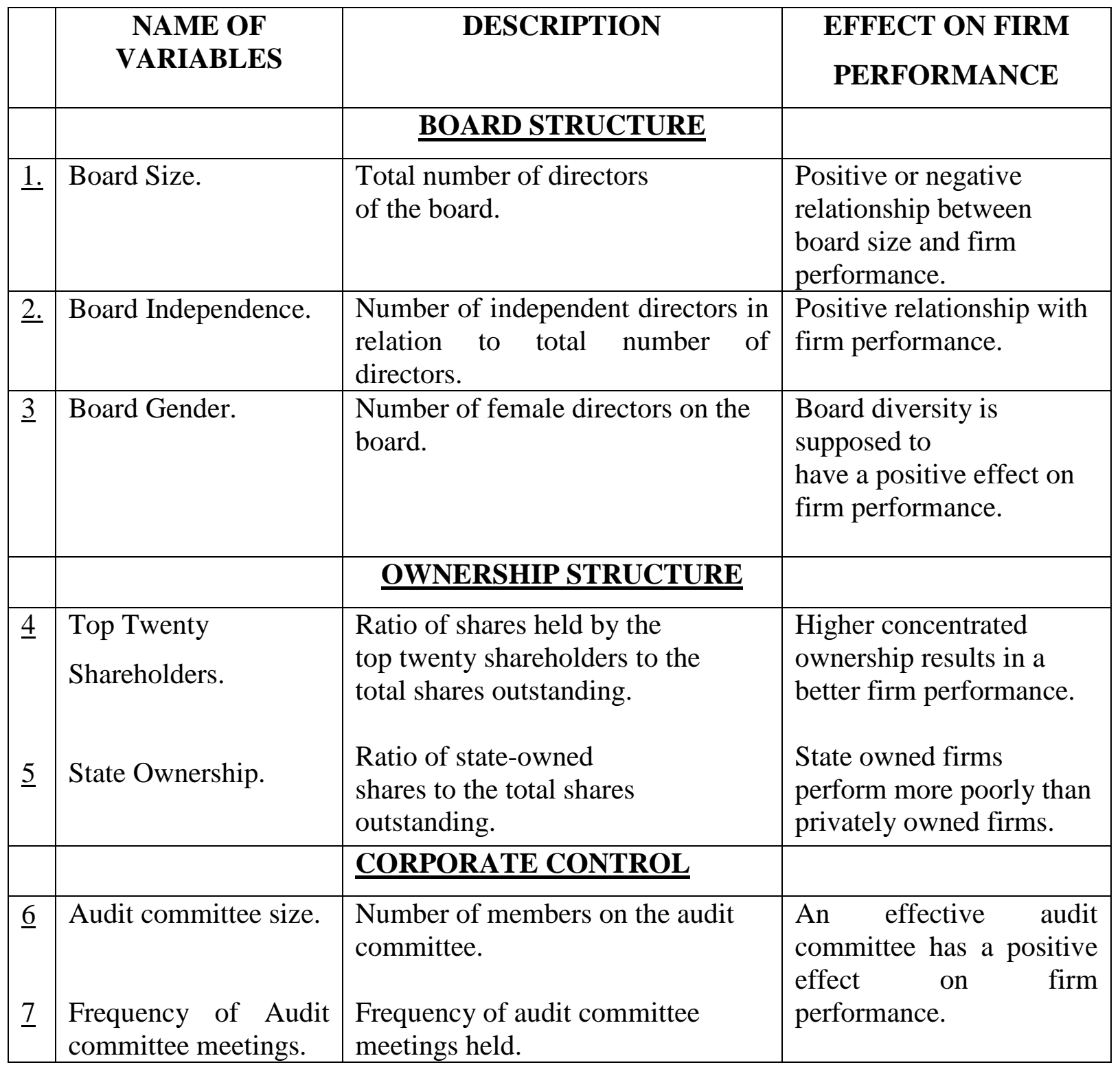




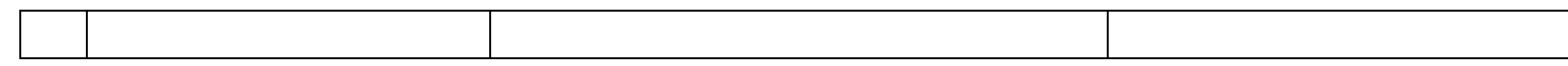

Table 2.0 Operational Definitions

\begin{tabular}{|l|l|l|}
\hline VARIABLE & LABEL & OPERATIONALIZATION \\
\hline Return on Equity & ROE & Net Profit/ Total Equity \\
\hline Return on Assets & ROA & Net Income/ Total Assets \\
\hline Net Profit Margin & NPM & Net Income/ Total Sales \\
\hline Tobin's Q & TBQ & $\begin{array}{l}\text { (Market Size+ Total Asset- Total Equity)/ } \\
\text { Total Assets }\end{array}$ \\
\hline
\end{tabular}

Model

The research adopts a model similar to that adopted by Abor and Biekpe (2007) who used firm performance as a function of board and ownership structure. Their model was Performance $=\alpha+\beta$ (board $)+\delta$ (ownership) $+\mathrm{K}$ (control factors $)+\mu$. However, the general panel regression model for analysing cross-sectional and time series data is adopted and further expanded to include all the indices covered in the study.

$$
\mathbf{Y}_{\text {it }}=\alpha+\mathbf{b x} \text { it }+\varepsilon_{\text {it }}
$$

Where

$\mathrm{Y}=$ Dependent variables (ROA, ROE, NPM, Tobin’s Q)

$\mathrm{x}=$ Independent variables (BS, BG, BI, TTS, SOS, FM, SAC, SZE, AGE, DBS)

$\alpha$ and $b=$ Coefficients

$\mathrm{i}$ and $\mathrm{t}=$ cross-sectional and time-series dimensions

$\varepsilon=$ Error term

The various models are defined as follows.

1.

$$
\mathrm{ROA}=\alpha+\beta \mathrm{BS}+\beta \mathrm{BG}+\beta \mathrm{BI}+\beta \mathrm{TTS}+\beta \mathrm{SOS}+\beta \mathrm{FM}+\beta \mathrm{SAC}+\beta \mathrm{SZE}+\beta \mathrm{AGE}+
$$
$\beta \mathrm{DBS}+\varepsilon$

2. $\quad \mathrm{ROE}=\alpha+\beta \mathrm{BS}+\beta \mathrm{BG}+\beta \mathrm{BI}+\beta \mathrm{TTS}+\beta \mathrm{SOS}+\beta \mathrm{FM}+\beta \mathrm{SAC}+\beta \mathrm{SZE}+\beta \mathrm{AGE}+$ $\beta \mathrm{DBS}+\varepsilon$

3. $\quad \mathrm{NPM}=\alpha+\beta \mathrm{BS}+\beta \mathrm{BG}+\beta \mathrm{BI}+\beta \mathrm{TTS}+\beta \mathrm{SOS}+\beta \mathrm{FM}+\beta \mathrm{SAC}+\beta \mathrm{SZE}+$ $\beta \mathrm{AGE}+\beta \mathrm{DBS}+\varepsilon$

4. $\quad \mathrm{TBQ}=\alpha+\beta \mathrm{BS}+\beta \mathrm{BG}+\beta \mathrm{BI}+\beta \mathrm{TTS}+\beta \mathrm{SOS}+\beta \mathrm{FM}+\beta \mathrm{SAC}+\beta \mathrm{SZE}+\beta \mathrm{AGE}+$ $\beta \mathrm{DBS}+\varepsilon$ 
Where

$\mathrm{Y}=$ Dependent variables (ROA, ROE, NPM, Tobin's Q)

$\mathrm{x}=$ Independent variables (BS, BG, BI, TTS, SOS, FM, SAC, SZE, AGE, DBS)

$\alpha$ and $b=$ Coefficients

$\mathrm{i}$ and $\mathrm{t}=$ cross-sectional and time-series dimensions

$\varepsilon=$ Error term

\section{Findings}

\begin{tabular}{|l|c|c|c|c|c|}
\hline VARIABLE & MEAN & MEDIAN & STD DEV & MIN & MAX \\
\hline Board Size & 9.095745 & 9 & 2.048179 & 6 & 14 \\
\hline Executive Directors & 3.071429 & 3 & 1.604104 & 1 & 7 \\
\hline Non- Executive Directors & 5.892857 & 5.5 & 1.735649 & 3 & 10 \\
\hline Male & 7.611111 & 7.5 & 1.752651 & 4 & 11 \\
\hline Female (Board diversity) & 1.455556 & 1 & 0.9848414 & 0 & 4 \\
\hline Audit Committee Size & 3.942857 & 4 & 1.08862 & 2 & 7 \\
\hline Freq. of Audit Meetings & 7.54 & 5.5 & 4.366898 & 1 & 15 \\
\hline Top 20 share ownership & 83.25756 & 86.68 & 10.36681 & 54.67 & 96.02 \\
\hline State ownership & 9.751495 & 0 & 17.69904 & 0 & 51.1 \\
\hline AGE & 45.7000 & 44 & 23.50607 & 17 & 117 \\
\hline SZE & 8.202602 & 8.179353 & 0.7013089 & 6.523828 & 9.535049 \\
\hline DBS & 0.7497971 & 0.7596479 & 0.6573081 & 0.1076564 & 6.868094 \\
\hline ROA & 5.553564 & 3.873085 & 7.942914 & -13.44023 & 29.65137 \\
\hline ROE & -82.50871 & 18.13734 & 824.3728 & -8069.237 & 59.73655 \\
\hline NPM & 11.41533 & 11.48242 & 15.43508 & -37.21357 & 61.19115 \\
\hline TOBIN'S Q & 1.458058 & 1.120609 & 0.915152 & 0.099868 & 4.72146 \\
\hline
\end{tabular}

Table 4.1 reports an average/mean board size of nine board members amongst the 20 sampled companies listed on the Ghana Stock Exchange. The analysis also reveals that on average listed firms have three (3) internal board members (executive directors) and approximately 6 external board members (non-executive directors). This implies that on average, there are more non-executive directors than executive directors, suggesting a high level of independence on the board which conforms to the Ghana Stock Exchange listing requirements of a minimum of four (4) non-executive directors on a company's board. Also, the ratio of male board members to female board members was found to be $7: 1$ which implies that board diversity among listed firms is low. 
As shown in Table 4.1 on average, the top twenty shareholders hold about $83.26 \%$ of the company's shares thus ownership is concentrated among a few shareholders. This result corroborates the findings of Salami (2011) who found that most of the listed companies on the Ghanaian stock exchange had very high ownership concentrations. The analysis also reveals that the state ownership on average is about $9.75 \%$ of total shares outstanding implying low government influence among listed firms on the Ghana Stock Exchange. The analysis on corporate control also indicates that on average, listed companies have 4 members on their audit committee ranging from a minimum of 2 to a maximum of 7 and the audit committee held an average of 8 meetings annually, varying between 1 to 15 times in a year. Table 4.1 reports on some performance indicators of the sampled firms from the Ghana Stock Exchange. It shows that the average Return on Asset (ROA) was 5.55\%, Return on Equity was -82.42\%, Net profit Margin was 11.42\% while Tobin’s Q was 1.458057\%. Furthermore, the table also reports that the average age of the sampled companies was 45.7 years while the average firm size was 8.202602 with firm size indicated by the natural log of the firms' capitalization. Finally, the average debt to equity ratio for the sampled companies was reported to be 0.7497971 .

\section{Multicollinearity Test}

A multicollinearity test is conducted to ascertain whether the independent variables have a strong correlation among themselves. The test is important because the reliability of the results is questionable in the event of the existence of multicollinearity. All other things being equal, researchers desire higher levels of tolerance, as low levels of tolerance are known to adversely affect the results associated with a multiple regression analysis. Various recommendations for acceptable levels of tolerance have been published in the literature. According to Tabachnick and Fidell (2001), the minimum level of tolerance recommended is a value of 0.10 whereas Menard (1995) recommended the use of 0.20 as the minimum value and 0.25 by Huber and Stephens (1993).

Table 4. 1: Variance Inflation Factor and Tolerance levels of Independent Variables

\begin{tabular}{l|ll}
\hline Variable & VIF & Tolerance level (1/VIF) \\
\hline BS & 2.38 & 0.420075 \\
AGE & 2.14 & 0.46716 \\
DBS & 1.75 & 0.570689 \\
SIZE & 1.70 & 0.589835
\end{tabular}




\begin{tabular}{l|ll} 
SOS & 1.68 & 0.594740 \\
TTS & 1.67 & 0.598509 \\
BI & 1.63 & 0.612415 \\
BG & 1.48 & 0.674595 \\
SAC & 1.43 & 0.744141 \\
\hline Mean VIF & $\mathbf{1 . 7 5}$ & \\
\hline
\end{tabular}

Table 4.2 shows that the tolerance levels are all higher than the minimum recommended values and therefore implies that the level of correlation between the independent variables are small and will not increase the standard errors significantly. Therefore multicollinearity is not a problem in the models estimated below.

Regression Results

Table 4. 2: Regression Model (Dependent Variable: Return on Asset)

\begin{tabular}{l|llll}
\hline Variable & Coefficient & Std. Error & t-statistic & Prob. \\
\hline CONSTANT & 14.39775 & 16.46431 & 0.87 & 0.386 \\
BS & -.8893935 & .7025447 & -1.27 & 0.211 \\
BI & -26.7383 & 10.13664 & -2.64 & 0.011 \\
BG & -.0897605 & 12.37466 & -0.01 & 0.994 \\
FM & -0.8197644 & 0.3666621 & -2.24 & 0.032 \\
TTS & .2893576 & .1182329 & 2.45 & 0.018 \\
SOS & .0834645 & .1093657 & 0.76 & 0.449 \\
SAC & .4786649 & 1.19128 & 0.40 & 0.690 \\
AGE & .2082823 & .0880447 & 2.37 & 0.022 \\
SIZE & -1.96193 & 1.71972 & -1.14 & 0.259 \\
DBS & -1.666774 & 1.633173 & -1.02 & 0.312 \\
\hline & & & & \\
\hline R - squared & 0.4221 & & F - Statistic & 2.34 \\
Adj. R - squared & 0.2415 & Prob. (p-value) & 0.0335 \\
\hline
\end{tabular}

Table 4.3 indicates that Board size (BS) has a negative but insignificant relationship with ROA. The negative association suggests that companies with a relatively lower board size tend to perform better with regards to ROA than companies with a larger board size. The findings of the negative association consolidates the findings in Lipton and Lorsch (1992) and Jensen (1993) who concluded that smaller boards are more efficient as against larger boards. The regression results also reveal a $(\mathrm{p}<0.05)$ significant negative $(-26.7383)$ 
relationship between board independence and ROA. This suggests that listed companies with a relatively lower number of non-executive directors tends to perform better in terms of ROA than companies with a larger percentage of non-executive directors. This result contradicts Abor and Biekpe (2007) who found a significant positive relationship between board independence and firm profitability.

Table 4.3 revealed that Board gender (BG) has a negative but insignificant impact on ROA. It also shows that the number of times audit committee meetings were held had an influence on performance as given by the p-value of 0.032 . Thus the number of times audit meetings were held in a firm negatively affected ROA. The number of members on the audit committee does not have a significant impact on ROA at a 5\% level of confidence as its p-value was 0.690. Results on the impact of ownership structure on performance are also presented in the table above. The proportion of shares held by the top 20 shareholders has a positive and significant impact on Return on Assets (ROA) at the 5\% level of confidence. This result agrees with Zhuang (1999) who indicates that companies with higher concentrated ownership structures perform better than their counterparts. Ratio of state owned shares to total shares outstanding (SOS) however has a positive but insignificant impact on ROA as its p-value was 0.449.

Table 4. 3: Regression Model (Dependent Variable: Return on Equity)

\begin{tabular}{l|llll}
\hline Variable & Coefficient & Std. Error & t-statistic & Prob. \\
\hline CONSTANT & -29.88866 & 35.37073 & -0.85 & 0.402 \\
BS & -1.757584 & 1.509296 & -1.16 & 0.250 \\
BI & -48.55246 & 21.77682 & -2.23 & 0.030 \\
BG & 23.5524 & 26.58483 & 0.89 & 0.380 \\
FM & -2.146939 & 0.735061 & -2.92 & 0.006 \\
TTS & .2483074 & .2540031 & 0.98 & 0.333 \\
SOS & .3348998 & .2349533 & 1.43 & 0.160 \\
SAC & 1.919521 & 2.559275 & 0.75 & 0.457 \\
AGE & .2249509 & .1891489 & 1.19 & 0.240 \\
SIZE & 6.75072 & 3.694522 & 1.83 & 0.044 \\
DBS & -4.452213 & 3.50859 & -1.27 & 0.210 \\
\hline & & & & \\
\hline R-squared & 0.4436 & & F-Statistic & 2.55 \\
Adj. R-squared & 0.2698 & & Prob. (p-value) & 0.0216 \\
\hline
\end{tabular}


On the impact of board composition on performance, results in Table 4.4 indicates that board independence (BI) to has a negative and significant impact on Return on Equity as its p-value of 0.030 is less than the $5 \%$ level of confidence. This suggests that a unit increase in the number of non-executives would negatively impact on ROE. Results also suggest a negative relationship between Board size (BS) and ROE but this relation according to Table 4.4 was insignificant as its p-value was 0.250 which is higher than the $5 \%$ level of confidence. Board gender or the proportion of female board members does have a positive but insignificant impact on Return on Equity. Table 4.4 also reports on the impact of corporate control on firm performance. The number of times companies hold audit meetings is shown by Table 4.4 to have a negative and significant influence on Return on Equity. Findings indicate that the number of members on the audit committee (SAC) does not significantly influence Return on Equity as its p-value lies above the $5 \%$ level of confidence. With respect to the impact of ownership structure on performance, Table 4.4 indicates that the ratio or percentage of shares held by the top 20 shareholders to the total shares outstanding does have a positive but insignificant impact on Return on Equity as its p-value (0.333) lies above the 5\% level of confidence. Also the ratio of state-owned shares to the total shares outstanding does not have a significant influence on Return on Equity.

Table 4. 4: Regression Model (Dependent Variable: Net Profit Margin)

\begin{tabular}{l|llll}
\hline Variable & Coefficient & Std. Error & t-statistic & Prob. \\
\hline CONSTANT & & & & \\
BS & -1.638836 & 1.001218 & -1.64 & 0.108 \\
BI & -12.38133 & 14.44603 & -0.86 & 0.395 \\
BG & 36.65193 & 17.63551 & 2.08 & 0.043 \\
FM & -0.6248072 & 0.5239308 & -1.19 & 0.242 \\
TTS & 0.1378722 & .1684973 & 0.82 & 0.417 \\
SOS & -.2422159 & .1558603 & -1.55 & 0.126 \\
SAC & 3.277553 & 1.697739 & 1.93 & 0.059 \\
AGE & 0.241896 & .1254752 & 1.93 & 0.049 \\
SIZE & 11.90848 & 2.450825 & 4.86 & 0.000 \\
DBS & -0.0792751 & 2.327484 & 0.03 & 0.973 \\
\hline & & & & \\
\hline R - squared & 0.5573 & & F - Statistic & 4.03 \\
Adj. R - squared & 0.4189 & & Prob.(p-value) & 0.0012 \\
\hline
\end{tabular}


Table 4.5 presents the regression model with Net Profit Margin as the dependent variable and the explanatory variables use in the previous models. With respect to the impact of the board composition on performance, results in Table 4.5 indicate board size to have a negative but insignificant impact on Net Profit Margin of the sampled firms. Unlike findings in our previous models where board independence had a significant impact on performance, board independence has a negative but insignificant impact on Net Profit Margin. Board Gender (board diversity) however, is shown to have a positive and a significant influence on Net Profit Margin. The positive relation between board gender and performance (Net Profit Margin) conforms with the findings of Fondas and Sassalos (2000) and Carter et al. (2003). The number of audit meetings held shows no significant influence on performance (NPM) since the p-value was 0.242. The coefficient of the number of members on the audit committee is 3.277553 and its p-value is 0.059 , this suggests that the size of audit committee does not influence Net Profit Margin at the 5\% level of confidence. Considering the impact of ownership structure on performance, Table 4.5 reports that the proportion of outstanding shares held by the top twenty shareholders has a positive but insignificant influence on Net Profit Margin. The positive relation supports the findings of Zhuang (1999) who asserted that high level of ownership concentration are more effective in monitoring the activities of management. On the other hand, the proportion of outstanding shares held by the state has been shown to have a negative but insignificant impact on Net Profit Margin.

Table 4. 5: Regression Model (Dependent Variable: Tobin’s q)

\begin{tabular}{l|llll}
\hline Variable & Coefficient & Std. Error & t-statistic & Prob. \\
\hline CONSTANT & 0.5363313 & 1.970829 & 0.27 & 0.787 \\
BS & -0.0602522 & 0.0843653 & -0.71 & 0.479 \\
BI & -0.473477 & 1.198990 & -0.39 & 0.695 \\
BG & 2.410052 & 1.503104 & 1.60 & 0.115 \\
FM & -0.0863936 & 0.048234 & -1.79 & 0.083 \\
TTS & 0.0303281 & 0.013961 & 2.17 & 0.035 \\
SOS & -0.0115636 & 0.0131307 & -0.88 & 0.383 \\
SAC & -0.1010056 & 0.1482196 & -0.68 & 0.499 \\
AGE & 0.0276022 & 0.0115537 & 2.39 & 0.021 \\
SIZE & -0.2095559 & 0.2041168 & -1.03 & 0.310 \\
DBS & 0.0529347 & 0.1954531 & 0.27 & 0.788 \\
\hline
\end{tabular}




\begin{tabular}{l|lll} 
& & & \\
\hline R - squared & 0.2451 & F - Statistic & 2.73 \\
Adj. R -squared & 0.1036 & Prob.(p-value) & 0.047 \\
\hline
\end{tabular}

Table 4.6 presents the regression model with Tobin's Q as the dependent variable and the same independent variables use in the previous models. Table 4.6 indicate board size to have a negative but insignificant impact on Tobin's Q of the sampled firms. Board independence has a negative but insignificant impact on Tobin's Q. Board Gender (board diversity) is shown to have a positive and insignificant influence on Tobin's Q. Also the number of audit meetings does not have a significant impact on Tobin's $Q$ at the $5 \%$ level of confidence. Table 4.6 also reports the coefficient of the number of member on the audit committee as having a negative but insignificant impact on Tobin's $Q$ as its p-value was 0.499 suggesting that the size of audit committee does not influence Tobin's $Q$ at the $5 \%$ level of confidence. In terms of ownership structure the proportion of outstanding shares held by the top twenty percent of shareholders has a positive and a significant influence on Tobin's Q. The positive relationship supports the findings of Zhuang (1999) who asserted that high level of ownership concentration increases shareholder effectiveness in monitoring the activities of management. However, the proportion of outstanding shares held by the state has been shown to have a negative but insignificant impact on Tobin’s Q.

\subsubsection{ANOVA ANALYSIS OF BOARD SIZE}

Table 4. 6: The impact of Board size on ROA, ROE, NPM and Tobin's Q

\begin{tabular}{|l|l|l|l|l|l|}
\hline BS & Freq. & $\begin{array}{l}\text { Mean } \\
\text { (ROA) }\end{array}$ & $\begin{array}{l}\text { Mean } \\
\text { (ROE) }\end{array}$ & $\begin{array}{l}\text { Mean } \\
\text { (NPM) }\end{array}$ & $\begin{array}{l}\text { Mean } \\
\text { (Tobin's Q) }\end{array}$ \\
\hline Less than 8 & 40 & 6.12208 & 17.0629 & 14.0962 & 1.5258 \\
\hline 9 to 11 & 41 & 5.77912 & 21.8297 & 12.6373 & 1.34296 \\
\hline Greater than 11 & 19 & 3.86995 & -517.284 & 3.13437 & 1.54896 \\
\hline F- Statistic & & $\mathbf{1 . 2 0}$ & $\mathbf{1 . 6 6}$ & $\mathbf{2 . 0 8}$ & $\mathbf{1 . 1 2}$ \\
\hline P-Value & & $\mathbf{0 . 3 1 0 4}$ & $\mathbf{0 . 1 1 9 4}$ & $\mathbf{0 . 0 4 6 7}$ & $\mathbf{0 . 3 6 1 9}$ \\
\hline
\end{tabular}

Table 4.7 presents the ANOVA results for the impact of board size on ROA, ROE, NPM and Tobin's Q. The sampled companies have been classified into three groups. As shown above, 
companies with a board size of less than 8 members had an average ROA of 6.12208, those with a board size from 9 to 11 had an average ROA of 5.77912 and those with a board size greater than 11 had an ROA of 3.86995. This suggests that companies with a relatively smaller board size tend to perform better than companies with a relatively larger size. However with an F-Statistic value of 1.20 and a P-value of 0.3104 , we conclude that there is no significant difference between the mean ROA for companies with different board sizes. Thus, board size does not have a significant impact on ROA. Board size also showed no significant impact on ROE having recorded an F-statistic value of 1.66 and a p-value of 0.1194. Companies within the first group (Less than 8 board members) had an average ROE of 17.0629, with those in the second group (9-11 board members) recording an average ROE of 21.8297 and an average ROE of -517.284 for those in the third group (board members greater than 11).

Table 4.7 also presents results on the impact of board size on NPM and Tobin's Q. NPM was 14.0962 for a board size of 8 members and less, this decreased slightly to 12.6373 when the board size increased to 9 to 11 members. There was a further decrease to 3.13437 as the board size increased to 11 members and more. The F-statistic value of 2.08 and a P-value of 0.0467 indicate a significant impact of the size of the board on NPM. There was however no clear pattern discovered in the results of the Tobin's Q. The first group (less than 8 members) recorded a Tobin's Q of 1.5258, while Tobin's Q for the second group (9-11 members) was 1.34296, increasing to 1.54896 for the above 11 board members group .Given a p-value of 0.3619 , the impact of board size on Tobin's Q was concluded to be insignificant.

\subsubsection{ANOVA ANALYSIS OF BOARD INDEPENDENCE}

Table 4. 7: Impact of Board Independence on ROA, ROE, NPM and Tobin's Q

\begin{tabular}{|l|l|l|l|l|c|}
\hline BI & Freq. & $\begin{array}{l}\text { Mean } \\
\text { (ROA) }\end{array}$ & $\begin{array}{l}\text { Mean } \\
\text { (ROE) }\end{array}$ & $\begin{array}{l}\text { Mean } \\
(\mathbf{N P M )}\end{array}$ & $\begin{array}{l}\text { Mean } \\
\text { (Tobin's Q) }\end{array}$ \\
\hline Less than 5 & 42 & 7.46858 & 21.3462 & 16.791 & 1.69076 \\
\hline 6 to 8 & 37 & 4.05727 & 15.0776 & 11.6835 & 1.28716 \\
\hline Greater than 8 & 21 & 4.35987 & -462.156 & 0.191599 & 1.69076 \\
\hline F- Statistic & & $\mathbf{1 . 2 9}$ & $\mathbf{4 . 9 9}$ & $\mathbf{3 . 1 4}$ & $\mathbf{1 . 1 0}$ \\
\hline
\end{tabular}




\begin{tabular}{|l|l|l|l|l|l|}
\hline P-Value & & 0.2683 & 0.0001 & 0.0058 & 0.3735 \\
\hline
\end{tabular}

Table 4.8 above presents the ANOVA test for the impact of board independence on ROA, ROE, NPM and Tobin's Q. The ANOVA test was used to compare the averages of the four firm performance indicators based on the number of independent board members. Board Independence was classified under 3 groups with the first group having less than 5 nonexecutive members, second group with 6 to 8 non-executive members and the last group with more than 8 non-executive members. From the analysis, it can be inferred that the group with a relatively smaller number of non-executive directors performed better than companies with a relatively larger number of non-executive directors as depicted by the ROE of 21.3462 and NPM of 16.791 being the highest values. Mixed results were however discovered for the impact of board independence on the performance indicators. The p-value for ROE and NPM was 0.0001 and 0.0058 respectively implying that there is a significant impact of board independence on both ROE and NPM. However, no significant impact was recorded for ROA and Tobin's Q as their P-values of 0.2683 and 0.3735 were above the $5 \%$ acceptable error margin.

\subsubsection{ANOVA ANALYSIS OF BOARD GENDER}

Table 4. 8: Impact of Board Gender on ROA, ROE, NPM and Tobin's Q

\begin{tabular}{|l|l|l|l|l|l|}
\hline BG & Freq. & $\begin{array}{l}\text { Mean } \\
\text { (ROA) }\end{array}$ & $\begin{array}{l}\text { Mean } \\
\text { (ROE) }\end{array}$ & $\begin{array}{l}\text { Mean } \\
(\text { NPM) }\end{array}$ & $\begin{array}{l}\text { Mean } \\
\text { (Tobin's Q) }\end{array}$ \\
\hline Less than 2 & 78 & 5.05963 & -3.92852 & 11.0336 & 1.40306 \\
\hline Greater than 2 & 22 & 7.30478 & -361.111 & 12.7687 & 1.67498 \\
\hline F- Statistic & & $\mathbf{1 . 2 4}$ & $\mathbf{0 . 3 0}$ & $\mathbf{1 . 8 1}$ & $\mathbf{0 . 8}$ \\
\hline P-Value & & $\mathbf{0 . 3 0 1 7}$ & $\mathbf{0 . 8 7 5 6}$ & $\mathbf{0 . 1 3 3 9}$ & $\mathbf{0 . 5 2 6 9}$ \\
\hline
\end{tabular}

Table 4.9 reports on the impact of board diversity (BG) on firm performance. For this section only 2 classifications were used. The first group was made up of boards with less than 2 female directors while the second group was made up of boards with more than 2 female directors represented the second group. An increase in performance was identified for ROA, NPM and Tobin's Q as the number of females on the board became greater than 2, this was however not the case with ROE as the first group had an ROE of -3.9852, there was a further decrease to -361.111. Regardless of the above inferences, the P-values of ROA, ROE, NPM 
and Tobin's Q were $0.3017,0.8756,0.1339$ and 0.5269 respectively indicating that there is no significant impact of the board gender diversity on performance.

\subsubsection{ANOVA ANALYSIS OF TOP TWENTY OWNERSHIP STRUCTURE}

Table 4. 9: Impact of top twenty percent ownership on performance

\begin{tabular}{|r|c|c|c|c|c|}
\hline \multicolumn{1}{|c|}{ TTS } & Freq. & $\begin{array}{c}\text { Mean } \\
\text { (ROA) }\end{array}$ & $\begin{array}{c}\text { Mean } \\
\text { (ROE) }\end{array}$ & $\begin{array}{c}\text { Mean } \\
\text { (NPM) }\end{array}$ & $\begin{array}{c}\text { Mean } \\
\text { (Tobin's q) }\end{array}$ \\
\hline Less than 60 & 5 & 2.72979 & 4.23032 & 1.86201 & 1.04668 \\
\hline Gre to 80 & 30 & 5.76351 & 15.943 & 10.7136 & 1.4644 \\
\hline F-statistic & & 5.67388 & -134.62 & 12.4741 & 1.49162 \\
\hline p-value & & $\mathbf{1 . 0 0}$ & $\mathbf{0 . 4 9}$ & $\mathbf{1 . 7 0}$ & $\mathbf{1 . 2 1}$ \\
\hline
\end{tabular}

Table 4.10 presents the ANOVA analysis on the impact of the proportion of outstanding shares owned by the top twenty percent of shareholders on the firm's performance. The sampled companies were group into three and their average performance in terms of ROA, ROE, NPM and Tobin's Q. The ANOVA test reports an F-statistic of 1.00 with a p-value of 0.4830 by comparing the average ROA for the three groups. This implies no significant difference in ROA for the three groups and hence we conclude that the percentage of top twenty ownership does not have a significant impact on ROA. Similar results were discovered for ROE and Tobin's Q as their P- values were 0.9802 and 0.2752 respectively. Contrary to the findings above, the ANOVA test reported an F-statistic of 1.70 with a p-value of 0.0423 by comparing the average NPM for the three groups. This therefore implies significant difference in NPM for the three groups and hence the conclusion that the proportion of outstanding shares owned by the top twenty percent of shareholders does have a significant impact on NPM at the 5\% level of confidence.

\subsubsection{ANOVA ANALYSIS OF STATE OWNERSHIP}

Table 4. 10: Impact of the share of State ownership on Performance

\begin{tabular}{|c|c|c|c|c|c|}
\hline SOS & Freq. & $\begin{array}{c}\text { Mean } \\
\text { (ROA) }\end{array}$ & $\begin{array}{c}\text { Mean } \\
\text { (ROE) }\end{array}$ & $\begin{array}{c}\text { Mean } \\
\text { (NPM) }\end{array}$ & $\begin{array}{c}\text { Mean } \\
\text { (Tobin's Q) }\end{array}$ \\
\hline Less than 20 & 74 & 6.67593 & 18.8962 & 14.2875 & 1.61374 \\
\hline
\end{tabular}




\begin{tabular}{|r|c|c|c|c|c|}
\hline 20 to 40 & 16 & 3.04625 & -79.1616 & 7.85701 & 1.10631 \\
\hline Greater than 40 & 10 & 1.2598 & -838.26 & -4.14568 & 0.976279 \\
\hline F-statistic & & $\mathbf{2 . 2 4}$ & $\mathbf{6 . 5 0}$ & $\mathbf{4 . 4 5}$ & $\mathbf{1 . 2 3}$ \\
\hline p-value & & $\mathbf{0 . 0 4 6 2}$ & $\mathbf{0 . 0 0 0 0}$ & $\mathbf{0 . 0 0 0 5}$ & $\mathbf{0 . 3 0 0 1}$ \\
\hline
\end{tabular}

Table 4.11 presents the ANOVA analysis on the impact of the proportion of outstanding shares owned by the State on the firm performance. The sample companies were group into three and their average performance in terms of ROA, ROE, NPM and Tobin's Q were compared. The analysis revealed that a unit increase of state ownership in a firm, results in a reduction in firm performance. This was confirmed as the first group of companies with less than 20\% state ownership performed relatively better than the firms with state ownership greater than $40 \%$. The ANOVA test reported an F-statistic of 2.24 with a p-value of 0.0462 by comparing the average ROA for the three groups. This revealed a significant difference in ROA for the three groups and hence the conclusion that state ownership can affect ROA. This result is synonymous to that of ROE and NPM were p-values of 0.0000 and 0.0005 respectively were recorded signifying an impact of the share of state ownership on these variables. With Tobin's Q, the ANOVA test reported an F-statistic of 1.23 with a p-value of 0.3001 by comparing the average Tobin's $\mathrm{Q}$ for the three groups. This suggests that state ownership has no significant impact on Tobin's Q.

\subsubsection{ANOVA ANALYSIS OF AUDIT COMMITTEE SIZE}

Table 4. 11: Impact of Audit committee size on ROA, ROE, NPM and Tobin's Q

\begin{tabular}{|r|c|c|c|c|c|}
\hline \multicolumn{1}{|c|}{ SAC } & Freq. & $\begin{array}{c}\text { Mean } \\
\text { (ROA) }\end{array}$ & $\begin{array}{c}\text { Mean } \\
\text { (ROE) }\end{array}$ & $\begin{array}{c}\text { Mean } \\
\text { (NPM) }\end{array}$ & $\begin{array}{c}\text { Mean } \\
\text { (Tobin's Q) }\end{array}$ \\
\hline Less than 3 & 27 & 3.78484 & 13.8149 & 9.82241 & 1.53069 \\
\hline Greater than 3 & 73 & 6.20775 & -118.135 & 12.0045 & 1.42808 \\
\hline F-statistic & & 3.53 & $\mathbf{2 . 9 4}$ & $\mathbf{1 . 8 0}$ & $\mathbf{1 . 5 4}$ \\
\hline p-value & & $\mathbf{0 . 0 0 7 0}$ & $\mathbf{0 . 0 1 9 0}$ & $\mathbf{0 . 1 2 4 9}$ & $\mathbf{0 . 1 9 1 3}$ \\
\hline
\end{tabular}


Table 4.12 presents the ANOVA analysis of the impact of the audit committee size on firm performance. The sample companies were grouped into two and their average performance in terms of ROA, ROE, NPM and Tobin's Q reviewed. The ANOVA test reports an F-statistic of 3.53 with a p-value of 0.00070 by comparing the average ROA for the two groups. This implies a significant difference in ROA for both groups thus concluding the presence of a significant impact on the firm's ROA. This implies that companies with a larger audit size tend to perform better than companies with a smaller size. The ROE yielded the same results after a comparison of the averages of the two groups. The F-statistics and p-value were 2.94 and 0.0190 respectively. This therefore implies that the size of the audit committee has a significant impact on ROE. Contrary to the findings of ROA and ROE, our results indicates that the audit committee size does not have significant impact on both NPM and Tobin's Q as the F-statistics were reported to be 1.80 and 1.54 respectively and their p-values were 0.1249 and 0.1913 respectively.

\subsubsection{ANOVA ANALYSIS OF THE FREQUENCY OF AUDIT COMMITTEE MEETINGS}

Table 4. 12: Impact of Frequency of Audit committee meetings on ROA, ROE, NPM and Tobin's Q

\begin{tabular}{|l|l|l|l|l|l|}
\hline FM & Freq. & $\begin{array}{l}\text { Mean } \\
\text { (ROA) }\end{array}$ & $\begin{array}{l}\text { Mean } \\
\text { (ROE) }\end{array}$ & $\begin{array}{l}\text { Mean } \\
\text { (NPM) }\end{array}$ & $\begin{array}{l}\text { Mean } \\
\text { (Tobin's Q) }\end{array}$ \\
\hline Less than 5 & 25 & 7.90381 & 18.7373 & 13.0403 & 1.87772 \\
\hline 5 to 10 & 4 & -0.06698 & -2004.73 & 9.07691 & 0.824669 \\
\hline Greater than 10 & 71 & 5.90381 & -9.86464 & 10.9749 & 1.33448 \\
\hline F- Statistic & & $\mathbf{3 . 2 4}$ & $\mathbf{1 1 3 9 3 . 6 5}$ & $\mathbf{2 . 9 4}$ & $\mathbf{3 . 0 3}$ \\
\hline P-Value & & $\mathbf{0 . 0 0 3 9}$ & $\mathbf{0 . 0 0 0 0}$ & $\mathbf{0 . 0 0 7 6}$ & $\mathbf{0 . 0 0 6 8}$ \\
\hline
\end{tabular}

Table 4.13 compares the average ROA, ROE, NPM and Tobin's Q for firms based on how frequently audit meetings are held. The frequency of Audit meetings were put into 3 groups , the first being less than 5 meetings a year, second group being between 5 to 10 meetings and the last group having more than 10 meetings. The average ROA for firms with less than 5 meetings per year was 7.90381, firms who held $6-10$ meetings was -0.06698 and 5.90381 for firms who held more than 10 audit meetings. The F-statistic was 3.24 with p-value of 0.0039 , indicating that the frequency of audit committee meetings has a significant impact on 
firm performance (ROA). The remaining performance indicators ROE, NPM and Tobin's Q yield the same results as did ROA. Their p-values were $0.0000,0.0076$ and 0.0068 respectively indicating that the number of meetings held by the audit committee has a significant impact on firm performance.

\subsubsection{ANOVA ANALYSIS OF FIRM AGE}

Table 4. 13: Impact of Age on Performance

\begin{tabular}{|r|c|c|c|c|c|}
\hline \multicolumn{1}{|c|}{ AGE } & Freq. & $\begin{array}{c}\text { Mean } \\
\text { (ROA) }\end{array}$ & $\begin{array}{c}\text { Mean } \\
\text { (ROE) }\end{array}$ & $\begin{array}{c}\text { Mean } \\
\text { (NPM) }\end{array}$ & $\begin{array}{c}\text { Mean } \\
\text { (Tobin's q) }\end{array}$ \\
\hline Less than 50 & 60 & 4.4551 & -150.655 & 10.0862 & 1.3268 \\
\hline 50 to 80 & 30 & 7.29171 & 16.6691 & 8.5345 & 1.68172 \\
\hline Greater than 80 & 10 & 6.92993 & 28.8385 & 28.0324 & 1.4992 \\
\hline F-statistic & & $\mathbf{5 . 3 9}$ & $\mathbf{1 . 0 4}$ & $\mathbf{2 0 . 8 2}$ & $\mathbf{3 . 1 7}$ \\
\hline p-value & & $\mathbf{0 . 0 0 0 0}$ & $\mathbf{0 . 4 1 7 6}$ & $\mathbf{0 . 0 0 0 0}$ & $\mathbf{0 . 0 0 1 1}$ \\
\hline
\end{tabular}

Table 4.14 presents the ANOVA results of the comparison of the average performance of the sampled companies. The age of the firm are classified into three groups. The results as shown in Table 4.13 indicate that the age of firms have a significant impact on ROA, NPM and Tobin's Q as their respective p-values are less than the 5\% level of confidence. The impact of firm age on ROE was however insignificant as its p-value was 0.4176 which lies above the $5 \%$ level of confidence.

\subsubsection{ANOVA ANALYSIS OF FIRM SIZE}

Table 4. 14: Impact of firm size on performance

\begin{tabular}{|r|c|c|c|c|c|}
\hline \multicolumn{1}{|c|}{ SAC } & Freq. & $\begin{array}{c}\text { Mean } \\
\text { (ROA) }\end{array}$ & $\begin{array}{c}\text { Mean } \\
\text { (ROE) }\end{array}$ & $\begin{array}{c}\text { Mean } \\
\text { (NPM) }\end{array}$ & $\begin{array}{c}\text { Mean } \\
\text { (Tobin's Q) }\end{array}$ \\
\hline Less than 8 & 68 & 6.77953 & -132.305 & 4.71675 & 1.58241 \\
\hline Greater than 8 & 32 & 2.96751 & 23.3094 & 25.6498 & 1.22539 \\
\hline F-statistic & & $\mathbf{1 . 9 1}$ & $\mathbf{0 . 4 1}$ & $\mathbf{2 2 . 8 9}$ & $\mathbf{1 . 7 0}$ \\
\hline p-value & & $\mathbf{0 . 1 3 3 6}$ & $\mathbf{0 . 7 4 4 7}$ & $\mathbf{0 . 0 0 0 0}$ & $\mathbf{0 . 1 7 3 7}$ \\
\hline
\end{tabular}


Table 4.15 presents the ANOVA test results for the sampled companies put into two groups based on their size. Size was computed by taking the natural log of the firms' total assets. The results indicates that firm size does not have a significant impact on ROA, ROE, and Tobin's $\mathrm{Q}$ as their respective p-values lies above the 5\% level of confidence. Table 4.14 however also shows that size of firm has a significant impact on NPM as its p-value was 0.0000 .

\subsubsection{ANOVA ANALYSIS OF FIRM'S DEBT TO ASSET RATIO}

Table 4. 15: Impact of debt to equity ratio on performance

\begin{tabular}{|r|c|c|c|c|c|}
\hline \multicolumn{1}{|c|}{ DBS } & Freq. & $\begin{array}{c}\text { Mean } \\
\text { (ROA) }\end{array}$ & $\begin{array}{c}\text { Mean } \\
\text { (ROE) }\end{array}$ & $\begin{array}{c}\text { Mean } \\
\text { (NPM) }\end{array}$ & $\begin{array}{c}\text { Mean } \\
\text { (Tobin's Q) }\end{array}$ \\
\hline Less than 3 & 89 & 5.6026 & -83.3574 & 11.509 & 1.46189 \\
\hline Greater than 3 & 11 & 0.699382 & 1.51478 & 2.14347 & 1.12061 \\
\hline F-statistic & & $\mathbf{1 4 . 1 5}$ & $\mathbf{0 . 1 8}$ & $\mathbf{0 . 4 0}$ & $\mathbf{7 . 7 5}$ \\
\hline p-value & & $\mathbf{0 . 0 0 0 0}$ & $\mathbf{0 . 8 3 2 7}$ & $\mathbf{0 . 6 7 4 4}$ & $\mathbf{0 . 0 0 0 8}$ \\
\hline
\end{tabular}

Table 4.16 also reports results for the impact of debt to equity ratio on performance. Table 4.16 shows the F-statistics and their respective p-values for the performance indicators. And from these results, debt to equity ratio has a significant impact on ROA and Tobin's Q as their respective p-values lie below the $5 \%$ level of confidence. However, debt to equity ratio has no significant impact on ROA and NPM.

\section{Discussion}

The first hypothesis (H1) suggests that there predict positive relationship between the number of independence and firm performance. The findings revealed a negative relationship between board independence and all the performance indicators. This implies that the performance of firms tends to decrease as the number of non-executive directors increased in relation to the executive directors. Therefore, the hypothesis is rejected. Our finding is consistent with previous studies (see.e.g Hermalin and Weisbach, 2001; 
Agrawal \& Knoeber,1996; Azez, 2015), and conclude that outsiders on the board does not help performance. While on the other hand, this is contrary to findings of studies such as Black et al. (2006); Abor and Biekpe (2007) and Chen et al., 2006. However, given the context of Ghana this raise the question of whether the non-executive directors truly fulfil the non-executive directors characteristics which recommended by the best practice code. The second hypothesis (H2) predicted that board size would negatively associated with the firm performance. Contrary to $\mathrm{H} 2$ the result show insignificant relationship implying that board size does not predict firm performance. Therefore, H2 is not supported. This result is in contrast with Ujunwa (2012) who asserted that board size has a significant negative relationship with firm performance. One possible explanation could be due to the sample size. It is more likely that in small samples where the majority of firms consisted of similar number of total number of directors, the results would not highlight the influence of board size. The third hypothesis (H3) suggests that the number of female directors on the board is positively associated with the performance. Our result revealed a positive and significant relationship with NPM which supports existing literature. This suggests that a unit increase in the number of females on the board of directors would result in increased profitability. However, a positive but insignificant relationship was established for both ROE and Tobin's Q.The fourth hypothesis (H4) suggests a positive relationship between ownership concentration and profitability. The results revealed a positive relationship with firm performance. There is strong evidence that the direct effect of ownership concentration on firm profitability in Ghana is positively and statistically significant, for ROA and Tobin's Q. Thus, we find evidence in support of Hypothesis (4). This finding suggest that companies with a higher ownership concentration amongst the top twenty shareholders performed better than companies with lower ownership concentration. This result confirms the finding of previous studies (see e.g. Zhuang,1999; Hiraki et al., 2003; Heugens et al., 
2009) who also asserted that companies with higher ownership concentration performed better. Moreover, the result for State ownership shows that there is no association with firm performance, thus, H5 is rejected. This finding is consist with the result of $\mathrm{Xu}$ and Wang (1999) who conclude that State ownership is considered irrelevant to the company profitability. Our finding did not find support $\mathrm{H} 6$ as the result indicates no relationship between audit committee size and company performance. Our result is consistent with previous studies (Rebeiz and Salameh, 2006; Sharma et al., 2009 Al-Mamun, 2014). Hypnosis 7 predicts that the number of audit comment meeting would be positively associated with firm performance. Contrary to H7, the result showed a significant negative relationship between number of audit committee meetings and ROE and ROA. The result in consistent with (Menon and Williams, 1994). This could be due to the increased costs for holding frequent meetings as well as the reverse in changes of decision taken in earlier meetings (Al-Mamun, 2014).

\section{CONCLUSION AND IMPLICATIONS}

Corporate Governance has been identified as a very intense and controversial area aspect of the business administration literature. The increasing need to understand the relationship between governance and firm performance is therefore of the essence (Kraus and Britzelmaier 2011). This study examined the relationship between corporate governance and firm performance of listed firms in Ghana. The corporate governance indicators used for this study included board size, board independence, board gender, ownership structure and effective audit committee. We demonstrated a mixed result in terms of the impact of corporate governance on firm performance. This in our view demonstrates the need not only for a uniform corporate governance code for companies operating in an emerging market but also the need for company specific approaches based on good governance practice. Across all the indicators used, our results demonstrate an overwhelming support for the impact of good corporate governance on firm performance. 


\section{LIMITATIONS OF THE STUDY}

A major limitation of the study is that data used is predominately collected from annual reports and thus may not be a true reflection of the state of affairs of the company since the regulatory and monitoring framework may be considered to be weaker in emerging markets than in matured markets. In addition, data used for the study covered a period of 5 years from 2008 to 2012 due to gaps in the data set outside of this range. We are of the view that a study covering a wider period could improve the quality of results generated. While we established a relationship between corporate governance and firm performance using companies across a range of industrial sectors, an industry based analysis of firms on the Ghanaian Stock Exchange, examining the relationship between director and board composition, ownership structure and corporate control would provide deeper insights into the specific impact corporate governance has on various industries based on their peculiar characteristics and operations. This was however not possible due to the small number of listed firms on the exchange. Increasing the number of variables explored by studying the impact CEO tenure and duality, board equity ownership, executive compensation and remuneration committees on performance, would no doubt increase the validity of the established relationship between good corporate governance and firm performance. Finally, due to missing data for some firms listed on the exchange, our study could not include all the listed firms on the exchange in our sample 


\section{References}

Abbott, L. J., Parker, S., Peters, G. F. and Raghunandan, K. (2000), 'The Effects of Audit Committee Activity and Independence on Corporate Fraud', Managerial Finance, 26(11), pp. 55-67.

Abbott, L., S. Parker, and G. Peters. 2004. Audit committee characteristics and restatements. Auditing: A Journal of Practice and Theory 23 (1), 69-87.

Ahunwan, Boniface. "Corporate governance in Nigeria." Journal of Business Ethics 37.3 (2002): 269-287.

Abor, J. and Biekpe, N. (2007) 'Corporate governance, ownership structure and performance of SMEs in Ghana: Implications for financing opportunities', Corporate Governance Journal, 7(3), pp. 288-300.

Adams, R. B., \& Ferreira, D. (2009). Women in the boardroom and their impact on governance and performance. Journal of financial economics, 94(2), 291-309.

Adams, R., and Mehran, H. (2005) 'Corporate performance, board structure, and its determinants in the banking industry', Working Paper Stockholm School of Economics.

Agrawal, A., \& Knoeber, C. R. (1996). Firm performance and mechanisms to control agency problems between managers and shareholders. Journal of financial and quantitative analysis, 31(03), 377-397.

Ahunwan, B. (2002) 'Corporate governance in Nigeria', Journal of Business Ethics, 37(3), pp. 269-87. 
Al-Mamun, A., Yasser, Q. R., Rahman, M. A., Wickramasinghe, A., \& Nathan, T. M. (2014). Relationship between audit committee characteristics, external auditors and economic value added (EVA) of public listed firms in Malaysia.CORPORATE OWNERSHIP \& CONTROL, 899.

Al-Najjar, B., \& Abed, S. (2014). The association between disclosure of forward-looking information and corporate governance mechanisms: Evidence from the UK before the financial crisis period. Managerial Auditing Journal, 29(7), 578-595.

Aydin, N., Sayim, M., \&Yalama, A. (2007). Foreign ownership and firm performance: Evidence from Turkey. International Research Journal of Finance and Economics, 11(2007), 103-111.

Azeez, A. A. (2015). Corporate Governance and Firm Performance: Evidence from Sri Lanka. Journal of Finance, 3(1), 180-189.

Bhagat, S. and Black, B. (2002) 'The non-correlation between board independence and long term firm performance’, Journal of Corporation Law, 27, pp. 231-274.

Bhagat, S., Black, B. and Blair, M. (2004) 'Relational investing and firm performance', Journal of Financial Research, 27, pp. 1-30.

Black, B, Jang, H. and Kim, W. (2006) 'Does Corporate Governance Predict Firms’ Market Values? Evidence from the Korean Market', Journal of Law, Economics, and Organization, 22(2), pp. 366-413.

Boardman, A.E. and Vining, A.R. (1989) 'Ownership and performance in competitive environments: a comparison of the performance of private, mixed and state-owned enterprises’, Journal of Law \& Economics, 32, pp. 1-33.

Bos, D. (1991). Privatization: a Theoretical Treatment. Clarendon Press, Oxford.

Braiotta, L. 2000. The Audit Committee Handbook - Second Edition. New York: John Wiley \& Sons, Inc.

Campbell, K., \& Mínguez-Vera, A. (2008). Gender diversity in the boardroom and firm financial performance. Journal of business ethics, 83(3), 435-451.

Carter, D. A., Simkins, B. J., \& Simpson, W. G. (2003). Corporate governance, board diversity, and firm value. Financial review, 38(1), 33-53.

Chapple, L., \& Humphrey, J. E. (2014). Does board gender diversity have a financial impact? Evidence using stock portfolio performance. Journal of business ethics, 122(4), 709-723. 
Chen, G., Firth, M., Daniel, N. G. and Rui, O. M. (2006) 'Ownership Structure, Corporate Governance, and Fraud: Evidence from China', Journal of Corporate Finance, 12(3), pp. 424-448.

Chen-Yu, C., Hui-Yu, C. Ming-Teh, W. (2006) 'Characterizing the corporate governance of UK listed construction companies', Construction Management and Economics, 24, pp. 647656.

Chen, Z., Cheung, Y. L., Stouraitis, A., \& Wong, A. W. (2005). Ownership concentration, firm performance, and dividend policy in Hong Kong. Pacific-Basin Finance Journal, 13(4), 431-449.

Cubbin, J. and Leech, D. ,1983, "The Effect of Shareholding Dispersion on the Degree of Control in British Companies: Theory and Measurement", Economic Journal 93 ,June, 351369 ,

Dalton, C. M., and Dalton, D. R. (2005) 'Boards of Directors: Utilizing Empirical Evidence in Developing Practical Prescriptions’, British Journal of Management, 16, pp. 91-97.

Dalton, D. R., Daily, C. M., Johnson, J. L., \& Ellstrand, A. E. (1999). Number of directors and financial performance: A meta-analysis. Academy of Management journal, 42(6), 674686.

Darmadi, S. (2013) 'Do women in top management affect firm performance? Evidence from Indonesia’, Corporate Governance Journal, 13(3), pp. 288-304.Eisenberg, T., Sundgren, S., $\&$

Wells, M. T. (1998). Larger board size and decreasing firm value in small firms. Journal of financial economics, 48(1), 35-54.

Eiteman, D.K., Stonehill, A. I. and Moffett, M. H. (2010) Multinational Business Finance, Pearson.

El Mir, A., \& Seboui, S. (2008). Corporate governance and the relationship between EVA and created shareholder value. Corporate Governance: The international journal of business in society, 8(1), 46-58.

Eng, L.L. and Mak, Y.T. (2003). Corporate governance and voluntary disclosure. Journal of Accounting and Public Policy. 22 (4), 325-345

Erhardt, N. L., Werbel, J. D., \& Shrader, C. B. (2003). Board of director diversity and firm financial performance. Corporate governance: An international review,11(2), 102-111. 
Fama, E.F. (1980) 'Agency problems and the theory of the firm', Journal of Political Economy, 88(2), pp. 288-307.

Fama, E. F., \& Jensen, M. C. (1983). Separation of ownership and control. Journal of law and economics, 301-325.

Farrell, K. A., \& Hersch, P. L. (2005). Additions to corporate boards: the effect of gender. Journal of Corporate finance, 11(1), 85-106.

Fondas, N. and Sassalos, S. (2000) 'A Different Voice in the Boardroom: How the Presence of Women Directors Affects Board Influence over Management', Global Focus, 12(2), pp. 13 -22 .

Hermalin, B., \& Weisbach, M. (2001) 'Boards of directors as an endogenously determined institution: a survey of the economic literature', National Bureau of Economic Research, Working Paper 8161, Cambridge, 391

Heugens, P., van Essen, M. and van Oosterhout, J. (2009). 'Meta-analyzing ownership concentration and firm performance in Asia: towards a more fine-grained understanding'. Asia Pacific Journal of Management, 26, 481-512.

Hiraki, T., Inoue, H., Ito, A., Kuroki, F., \& Masuda, H. (2003). Corporate governance and firm value in Japan: Evidence from 1985 to 1998. Pacific-Basin Finance Journal, 11(3), 239265.

Huber, E. D. R., and Stephens, J. D. (1993) 'The Impact of Economic Development on Democracy', Journal of Economic Perspectives, 7, pp. 71-85.

Jarboui, S., Guetat, H., \& Boujelbène, Y. (2015). Evaluation of hotels performance and corporate governance mechanisms: Empirical evidence from the Tunisian context. Journal of Hospitality and Tourism Management.

Jensen, M. (1993) 'The modern industrial revolution, exit, and the failure of internal control Systems', Journal of Finance, 48, pp. 831-880.

Jiang, B. B., Laurenceson, J., \& Tang, K. K. (2008). Share reform and the performance of China's listed companies. China Economic Review, 19(3), 489-501.

Joh, S.W (2003) 'Corporate governance and firm profitability: evidence from Korea before the economic crisis', Journal of Financial Economics, 68, pp. 287-322. 
Kalbers, L. P., \& Fogarty, T. J. (1993). Audit committee effectiveness: An empirical investigation of the contribution of power. Auditing, 12(1), 24.

Kang, H., Cheng, M., \& Gray, S. J. (2007). Corporate governance and board composition: Diversity and independence of Australian boards. Corporate Governance: An International Review, 15(2), 194-207.

Kiel, G.C., and Nicholson, G.J. (2003) 'Boards that work: A new guide for directors, McGraw Hill.

Koranteng, Eudora (2004) 'Corporate Governance', A paper presented at the Workshop for the Capital Markets for Media Practitioners, Accra.

Kraus, P. and Britzelmaier, B. (2011) 'Corporate Governance and Corporate Performance: A German Perspective’, International Journal of Management Cases, pp. 327 -340.

Krishnan, H. A. and Park D. A. (2005) 'A few good women: on top management teams', Journal of Business Research, 58(12), pp.1712-1720.

Kuznetsov, P., \& Muravyev, A. (2001). Ownership concentration and firm performance in Russia: the case of blue chips of the stock market. Acta Oeconomica, 51(4), 469-488.

La Porta, R., Lopez-de-Silanes, F., Shleifer, A., \& Vishny, R. (1999). The quality of government. Journal of Law, Economics, and organization, 15(1), 222-279.

Leonard-Barton, D., (1992) 'Core capabilities and core rigidities: A paradox in managing new product development', Strategic Management Journal, 13, pp.111-125.

Liao, J., \& Young, M. (2012). The impact of residual government ownership in privatized firms: New evidence from China. Emerging Markets Review, 13(3), 338-351.

Lipton, M., and Lorsch, J. W. (1992) 'A modest proposal for improved corporate governance’, Business Lawyer, 48(1), pp. 59-77.

Lo A.W. Y., Wong, R. and Firth, M. (2010) 'Can Corporate Governance Deter Management from Manipulation Earnings? Evidence from Related-Party Sales Transactions in China', Journal of Corporate Finance, 16(2), pp. 225-235.

Maher, M. and Anderson. T. (1999) 'Corporate Governance: Effects on Firm Performance and Economic Growth', Paper presented at the conference on Convergence and Diversity in 
Corporate Governance Regimes and Capital Markets, 4-5 November, Tilburg University, Tilburg, the Netherlands.

Mahmood, I. and Abbas, Z. (2011) 'Impact of Corporate governance on Financial performance of banks in Pakistan', Interdisciplinary Journal of Contemporary Research in Business, 2(12), pp. 217-228

Mardjono, A. (2005) 'A tale of corporate governance: lessons why firms fail', Managerial Auditing Journal, 20(3), pp. 272-283.

Menard, S. (1995) 'Applied logistic regression analysis', Sage University Paper Series on Quantitative Applications in the Social Sciences, 07-106, Thousand Oaks, CA: Sage.

Menon, K., \& Williams, J. D. (1994). The use of audit committees for monitoring. Journal of Accounting and Public Policy, 13(2), 121-139.

Mohd Saleh, N., Mohd Iskandar, T., \& Mohid Rahmat, M. (2007). Audit committee characteristics and earnings management: Evidence from Malaysia.Asian Review of Accounting, 15(2), 147-163.

Mollah, S., Farooque, O.A. and Karim, W. (2012) 'Ownership structure, corporate governance and firm performance: Evidence from an African emerging market', Studies in Economics and Finance, 29(4), pp. 301-319.

Monks, R.A.G. and Minow, N. (2011) Corporate Governance, John Wiley and Sons, Ltd.

OECD (2004) Principles of Corporate Governance, Available at http://www.oecd.org/corporate/ca/corporategovernanceprinciples/31557724.pdf, Assessed on July 15, 2013.N. Van der Walt, C. Ingley, G.S. Shergill, A. Townsend, (2006) "Board configuration: are diverse boards better boards?", Corporate Governance: The international journal of business in society, Vol. 6 Iss: 2, pp.129 - 147

Okeahalam, C.C (2004) 'Corporate governance and disclosure in Africa: Issues and Challenges', Journal of Financial Regulation and Compliance, 12(4), pp. 359-370.

Omane-Antwi, Kwame (2011) “Corporate Governance: A Catalyst for Organisational Success” A paper presented at the 6th Internal Audit Forum, Accra International Conference Centre, Accra. 
Raghunandan, K and Rama D V (2007), 'Determinants of Audit Committee Diligence', Accounting Horizons, 21(3), pp. 265-279.

Rebeiz, K. S., \& Salameh, Z. (2006). Relationship between governance structure and financial performance in construction. Journal of Management in Engineering, 22(1), 20-26.

Rees, W, and Sheikh, S, (1995), "Corporate governance and corporate control." London: Cavendish (1995).

Saibaba, M.D. and Ansar, V.A. (2013) 'Audit Committees, Board Structures and Firm Performance: A Panel Data Study of BSE 30 Companies', Journal of Accounting Research \& Audit Practices, 7(2), pp. 19-29.

Shah, A. A., Kouser, R., Aamir, M. and Hussain, C. M. (2012) 'The Impact of the Corporate Governance and the Ownership Structure on the Firm's Financial Performance and Its Risk Taking Behaviour', International Research Journal of Finance and Economics, 93, pp. 4455.

Sharma, V., Naiker, V. and Lee, B. (2009) 'Determinants of Audit Committee Meeting Frequency: Evidence from a Voluntary Governance System’, Accounting Horizons, 23(3), pp. 245-263.

Sheikh, J., Majid, K. M., Iqbal, W., Ahmed, W. S., and Masood, M. T. (2012) 'Examination of Theoretical and Empirical Studies on Firm's Performance in Relation to its' Board Size: A Study of Small and Medium Size Public Firms', Journal of Management Research, 4(2), pp. 242-254.

Sheikh, S and Rees, W (1995) Corporate Governance and Corporate Control, Cavendish Publishing Limited.

Shrader, C.B., Blackburn V.B. and Iles. P.(2007) 'Women in Management and Firm Financial Value: An Exploratory Study’, Journal of Managerial Issues, 9(3), pp. 355-373.

Sumit, K. M. (1997) 'The Impact of Size and Age on Firm-Level Performance: Some Evidence from India', Review of Industrial Organization, 12, pp. 231-241.

Tabachnick, B. G., and Fidell, L. S. (2001) 'Using multivariate statistics’, Needham Heights, MA: Allyn \& Bacon. 
Tsamenyi, M., Enninful-Adu, E. and Onumah, J. (2007) 'Disclosure and corporate governance in developing countries: evidence from Ghana', Managerial Auditing Journal, 22(3), pp. 319-334.

Ujunwa, A. (2012) 'Board characteristics and the financial performance of Nigerian quoted firms’, Corporate Governance Journal, 12(5) , pp. 656-674.

Vafeas, N. (1999). Board meeting frequency and firm performance. Journal of Financial Economics 53: 113-142.

Vafeas, N. (2000) 'Board Structure and the Informativeness of Earnings', Journal of Accounting and Public Policy, 19(2), pp. 139-160.

Vintila, G and Gherghina, S.C. (2012) 'An Empirical Investigation of the Relationship between Corporate Governance Mechanisms, CEO Characteristics and Listed Companies’ Performance’, International Business Research, 5 (10), pp.175-219.

Wang, M., \& Hussainey, K. (2013). Voluntary forward-looking statements driven by corporate governance and their value relevance. Journal of Accounting and Public Policy, 32(3), 26-49.

Wei, Z., Varela, O., Hassan, M. K. and D'souza, J. (2003) 'The financial and operating performance of China’s newly privatized firms’, Financial Management, 32, pp.107-126.

Wei, G. (2007). Ownership structure, corporate governance and company performance in China. Asia Pacific Business Review, 13(4), 519-545.

$\mathrm{Xu}, \mathrm{X}$. and Wang, Y. (1999) 'Ownership structure and corporate governance in Chinese stock companies', China Economic Review, 10, pp. 75-89.

Yermack, D. (1996) 'Higher market valuation of companies with a small board of directors', Journal of Financial Economics, 40, pp. 185-212.

Yige, M., Kilgore, A. and Wright, S. (2012) 'The Voluntary Formation of an Audit Committee', 2012 Financial Markets and Corporate Governance Conference, available at http://ssrn.com/abstract=1980484.

Zhang, Y., Cheng, Z. and Harvie, C. (2013) 'The Roles of Size and Size Difference in Australian and Chinese Inter-firm Collaborations', Australasian Accounting Business \& Finance Journal, 7(2), pp. 33-48. 
Zhuang, J. (1999). Corporate governance in East Asia and some policy implications. Asian Development Bank 